BARBARA LENA GIERSZEWSKA

Institute of Polish Philology Jan Kochanowski University in Kielce

\section{Cozy Homes? Rooms and apartments of the intelligentsia in Polish drama films, 1956-1970}

\begin{abstract}
Gierszewska Barbara Lena, Cozy Homes? Rooms and apartments of the intelligentsia in Polish drama films, 1956-1970. "Images" vol. XXII, no. 31. Poznań 2017. Adam Mickiewicz University Press. Pp. 91-102. ISSN 1731-450X. DOI 10.14746/i.2017.31.09.

The article presents the problems of private life of intellectuals in Poland "after Yalta" through the prism of the cinema. The biggest problem of people in the 1950s and 1960s was the lack of a satisfying home. The homes of young intellectuals shown in Polish films are the spectrum of dreams, most often impossible to achieve in real life. Apartments located in multi-family housing estates that immortalized in the Polish feature films between the years 1956-1970 are confirmation of the highest quality of Polish industrial design. Real people's apartments were cramped, ugly, and primitive.
\end{abstract}

Keywords: Polish film 1945-1970, architecture in communist Poland, Polish design of the 1950s and 1960s

In the period of the Polish People's Republic the homes of Poles living in cities were located primarily within the blocks of flats constructed in a mass scale. They were usually small (one- or two-bedroom) flats in blocks, which together made up residential estates for thousands of families. These apartments (hardly available, long awaited and dreamt of) became the focus of their inhabitants' attention, including the multitudes of the intelligentsia. In order to feel comfortably at home, residents almost immediately adapted their living spaces to suit their needs and, despite the lack of impact on the neighbourhood and budget limitations, they imparted their individual style to these dwellings. What were these homes like, how did people feel in them, did they have their way to experience intimacy or closeness in such homes, or perhaps were they more concerned with solitude, a place where they could hide themselves from the world? Answers to these questions can be found in Polish cinematography.

In this article I would like to explain how Polish cinema of the years 1956-1970 immortalized people in their homes, and to answer the question how important it was to have a home. I shall be concerned with movies seemingly insignificant in comparison with the masterpieces of the "Polish Film School" (which, of course, also deal with these topics), but it was mainly the Polish drama film that reflected "small stabilization" the spiritual and material condition of the Polish intelligentsia. By the way, the name "small stabilization" came into common circulation
Images vol. XXII/no. 31 Special Issue Poznań 2017 ISSN 1731-45OX 
thanks to the outstanding stage written by Tadeusz Różewicz Świadkowie albo nasza mała stabilizacja [Witnesses or Our Small Stabilization] published in 1962. The creator captured the everyday life malaise so characteristic of Poland in the $196 \mathrm{os}$, including, including the portrayals of intellectuals, seemingly happy people with professional careers but yet without faith in future prospects as to their expectations and possibilities. Through of the conduct of film characters depicted by a web of interrelationships, mainly in home interiors, among the items and accessories in their immediate environment, one can get an idea how different the members of the Polish intelligentsia were at the turn of the 1950s, (to paraphrase the words of Agnieszka Osiecka's song[1]) which problems tormented them, how they spent their time, what they dreamt of, what they aspired to at, etc., etc., etc. The period of "small stabilization" in our history lasted from October 1956 to the anti-intelligentsia and anti-Semitic provocations and attacks in 1968, and ended in the riots in Gdańsk in December 1970, which led to the displacement of the First Secretary of the Polish United Workers' Party "Comrade Wiesław" by Edward Gierek.[2] After a period of socialist realism for Poles it was the time of easing political tension and focus on one's own life.[3] Cinema of this genre captured in a suggestive form the previously hidden dreams and needs of the Poles who wanted to have a living space of their own. It showed that after the events of October 1956 personal affairs, including possessing one's own flat became very important.

Thanks to domestic film productions, which depicted real-life stories, cinema viewers could see many artistic visions of the livingconditions for a member of the Polish intelligentsia, and they could also find inspiration (in some sense to be transferred into real life). In the cinema of that time Polish viewers could see, therefore, not only the occupants of modern M-1, M-2 and M-3 apartments, [4] but also the tenants of temporarily developed living spaces. Sometimes the intelligentsia characters had to vegetate as lodgers in rented rooms of very different standard, or even inhabited in quarters designed for other functions. Occasionally, some members of the intelligentsia (mainly

[1] The song Okularnicy (lyrics by Agnieszka Osiecka, music by Jarosław Abramow) was popularized by Sława Przybylska.

[2] "Small stabilization", i.e. transformation of the socio-political system in the Polish People's Republic during the leadership of Władysław Gomułka ("Comrade Wiesław") was described, among others, by Piotr Osęka (Wiesław, odejdź [Wiesław, go away], "Polityka" 2010, no. 51, pp. 54-56). See also: Gomułka - the Great and the Small. An interview of Robert Walenciak with Adam Michnik, "Przegląd" 2011, no. 43, pp. 28-32. [3] "The Gomułka thaw" (also called "the October thaw" "the Polish October," or "October '56") lasted very briefly, in fact. The proverbial corner of one's own became a priority in the aspirations of Polish so- ciety from the mid 1950s; it was perceived as a retreat, protection of privacy.

[4] In the period of the Polish People's Republic, the living quarters were described by acronyms (depending on the number of persons that were to live in them and the number of rooms). M1 was a living quarter for 1 person (a so-called kawalerka), consisting of one room without a regular kitchen but with a kitchen annex instead, usually located in the hallway; M2 - a living quarter for two persons, consisting of one room and a kitchen; $\mathrm{M}_{3}$ - a living quarter for three persons, consisting of two rooms and a kitchen. See J. Suchecki, W cieniu 120 ooo $\mathrm{m}^{3}$ prefabrykatów rocznie, "Kronika Miasta Poznania" 2013 [no.] 3. pp. 283-291. 
architects, engineers, representatives of the artistic and intellectual circles, doctors, journalists, and athletes) occupied apartments of increased size or even owned detached houses. [5] Polish film of that time also recorded the homes of Party officials and other bureaucrats, who profited from "social advancement." Directors, chairmen of the works councils and party members could count on privileges when it comes to housing allocation: normally this was done "off the regular waiting list" resulting from the period of membership in a housing cooperative or they got premises, which before the war had been in private ownership and after its end had been taken over by the state.[6]

It is easy to imagine that for the film viewer of the "Gomułka era" accustomed to low housing standards, the apartments shown in Polish cinema of the late 1950 and 1960 s must have been an aesthetic shock. The interiors of the film characters' apartments were in fact created by prominent architects, designers and interior decorators. The decors of rooms and apartments designed in Poradnik matrymonialny [Matrimonial Guidebook], and installments 8-15 of Wojna domowa [War at Home] by Jerzy Zieliński, Polowanie na muchy and Dzięciot [Hunting Flies and Woodpecker] by Maciej Maria Putowski, Decyzja, Rozstanie, Sublokator, Przedświąteczny wieczór, Jutro Meksyk [Decision, Separation, Subtenant, Christmas Eve, Tomorrow Mexico] by Leonard Mokicz, Pingwin, Małżeństwo $z$ rozsądku, Katastrofa [Penguin, Marriage of Convenience, Catastrophe] by Wiesława Chojkowska, Żona dla Australijczyka, Barbara i Jan, Mą̇̇ swojej żony, Sposób bycia [Wife for an Australian, Barbara and John, Husband of his Wife, A Way of Life] by Zdzisław Staszewski, Otello $z$ M-2 [Othello from M-2] by Anatol Radzinowicz, Lekarstwo na miłość, Wycieczka w nieznane [Cure for Love, A Trip into the Unknown] by Teresa Gałkowska-Lesman, Sam pośród miasta [Alone in the City] by Marek Iwaszkiewicz - must have had a big influence on the Poles' tastes concerning a modern, optimally furnished house, or at least they familiarised film viewers with housing fashion trends around the world. The view of the actors in an elegant and generally functional and nicely furnished apartment, who were freely chatting over a good cup of coffee served in the "Ćmielów"[7]

[5] The family of architect Paweł Bączek (Pingwin [Penguin]) lived in a detached house. Ms Wiktoria with her daughter Ala and her subsequent husbands lived in a box house (To jest twój nowy syn [This Is Your New Son]). A certain dishonest director of the Provincial Construction Works, Markowski, owned a villa (Niedziela sprawiedliwości [A Sunday of Justice]). The villa of the sea captain Klement (a cousin of Robert Wolański, a Pole from Australia) is the setting of love adventures in the film Żona dla Australijczyka [A Wife for an Australian]. A former RAF officer, now a captain of the Polish Airlines "Lot", Ryszard Godzicki, lived in a modern villa with his English wife Mary (Sprawa pilota Maresza [The Case of Pilot Maresz]).
[6] By the force of the Decree of 21 December 1945 on public management of housing quarters and control of lease, the state took over a lot of private tenement houses. During the leadership of Władysław Gomułka housing co-operatives developed. In the years 1956-1960, about 450,000 dwellings were built, and in the years 1961-1970 - 1.7 million living quarters in housing estates. See K. Madej, Mieszkać w PRL, "Mówią Wieki" 2005, no. 1, pp. 34-39.

[7] Reference to Porcelain Plant in Ćmielów (established in 1790). In the factory nationalized after 1945, many dinner, coffee and tea sets as well as vases and figurines were designed and produced in innovative form and technology. Some of these designs were 
porcelain (Jutro Meksyk, Ich dzień powszedni [Their Common Day]), or listening to relaxing jazz music, [8] which came up straight from the home radio (or from record-players, as in Pingwin), offered Polish cinema audiences moments of hope that they would enjoy a similar existence in the future. We can only guess that the audience simpy took in the lifestyles of the artistic and intellectual spheres and the high-rank intelligentsia, and, at least mentally, they accepted their standards of living as desirable or representative for this category of people in the said period from October 1956 to the December 1970 events.

These films that tell stories about the life of the Polish intelligentsia during the drab "Gomułka era", naturally contributed to the creation of a specific social mythology, namely the hope for a dolce vita alla Polacca. The pinnacle of the dreams at the time of the "small stabilization" was to have "a small apartment in Mariensztat", to quote the title of the song of Irena Santor, [9] or in another newly built quarter of Warsaw an apartment that would have basic furnishings and amenities necessary for life and other (aesthetically desirable) items. The "small stabilization" of 1956-1970 was a period of expectations of Poles for the improvement in the quality of their lives, for an easier and more dignified existence. The visible symptom of change, however, was the relaxing of the "Iron Curtain," [10] which immediately paid off, among other thins, by the flow into Poland of news about the Western lifestyle. As is known, only a few citizens were able to leave for the West, but the fact that this limited number did go led to the appearance in Poland of Western clothes, food products, trinkets, industrial catalogues and other promotional and advertising publications which showed how diverse and rich "the capitalist world" was. Quickly, emerging resale shops offered Western clothing, cosmetics and all the goods that were not available Poland. And what is most important, the Polish press and radio began to write about the West; translations of foreign literature were made and Western contemporary art was exhibited. An important role in familiarising the Polish intelligentsia of big cities with the post-war West was played the Clubs

made under the patronage of Instytut Wzornictwa Przemysłowego [Institute of Industrial Design]. See B. Kołodziejowa, Zaklady Porcelany "Ćmielów". [8] After the end of World War II, jazz was condemned in Poland as "imperialist music." It was only after the death of Stalin that it was officially performed on the radio and at concerts.

[9] Małe mieszkanko na Mariensztacie [A Small Apartment in Mariensztat] was a popular song by Irena Santor with Wacław Stepień's lyrics and Zdzisław Gozdawa's music. After the premiere of the film Przygoda na Mariensztacie [Adventure in Mariensztat] (1953, dir. Leonard Buczkowski) the song was also performed by the main actors (who played bricklayers): Lidia Korsakówna i Tadeusz Szmidt. It is worth quoting a fragment of the song, the words of which reflect precisely the strivings of Poles "working their way up" and their modest dreams about a better life: A small apartment in Mariensztat - it's my happiness, it's my dreams. [...]/ It'll have a sofa and a Tesla radio./ a desk, curtains, two armchairs, a rug on the floor/ and some flowers on the mantelpiece, we shall buy a coffee set, some glassware. See $<$ http://www. irenasantor.pl/>.

[10] "The Iron Curtain" was a term popularized in 1946 by Winston Churchill, which referred to the territory of Central and Eastern Europe as a "Soviet zone." See Speeches of Winston Churchill March 5, 1946, <http://www.ntanet.net/sinewsofpeace.htm> [accessed on: 3.11.2015]. 
of International Press and Books, the only institutions of this kind where people could freely indulge in reading foreign newspapers, opinion weeklies and magazines.

Poles' knowledge about how people live in the West, however, was primarily drawn from the cinema. It started with a favourable change in cultural policy, thanks to which Poles had access to foreign movies. American films, Italian neo-realism, the French New Wave or the British Angry Young Men quickly became well known, at least among the intelligentsia (but not only this group). The possibility of looking at the model of existence other than the one binding in Poland, quickly resulted in the readiness of Poles to make a difference in their own lives. One can therefore believe that there was among the Poles at least an enthusiasm to imitate Western lifestyles. In some measure popular foreign films from the first decades after the war, in the late 1950 and 1960s, which gradually appeared in Polish cinemas, e.g. the American Pillow Talk (Telefon towarzyski, 1959, dir. Michael Gordon), the Italian Dolce Vita (1959, dir. Federico Fellini), La notte (Noc 1960, dir. Michelangelo Antonioni), and the English Look Back in Anger (Miłość i gniew, 1959, dir. Tony Richardson), not only provoked dramatic emotions among Polish viewers, but also longing and envy of the middle-class living standards in capitalism, although plenty of mud was slung at them by the Polish media.

In the 196os, Polish filmmakers transferred Western topics to the native land and made everyday human existence the basis of film plots. For this purpose, it was essential to adapt the scenery from American and West European interiors to Polish modest housing options, but it seems that designers succeeded, because to this day we watch with great interest films showing M-1, M-2, and M-3 apartments.[11] These are mostly homes located on urban housing estates, of modest size (35-50 m2), but thanks to the achievements of Polish designers, they are furnished skilfully and with attention to the smallest detail.

One may have the feeling that for some reason Polish film directors wanted to transplant the lifestyles of well-known from the "new wave" films and illustrated Western magazines to Polish ground. Fascinated by Antonioni, they took over from his films the convention of decorative interiors, which fitted into his vague films, suspended in a social vacuum and focused on the characters' own problems. Certainly, this must have charmed the Polish intelligentsia, but not only them. Our social cinema, which was founded in the 1950 and 1960s, showed vibrant cities, workplaces, cafes and neighbourhoods full of new dwellings inhabited largely by young people, who on the

[11] In Pillow Talk, Jan Morrow (played by Doris Day), relaxing in a bubble bath and speaking on the phone at the same time (played by Doris Day) may have introduced to Polish cinema a vogue for white telephone sets as well as actresses in a bath, which is discussed further in this article. One can generally observe "wandering motifs," "emulated dramatic situations," or "small realism" of social scenes in Polish film productions. See B. Drozdowski, Słownik współczesnej polszczyzny [Dictionary of the Contemporary Polish Language], "Kino" 1966, no. 7, pp. 2-9. 
one hand strove for their own happiness modelled on Western lifestyles and on the other were lost in "the lonely crowd." In a review of Hieronim Przybył’s film Poznańskie słowiki [Poznań Nightingales], Maria Keller drew the readers' attention to the "drama of high life" in the domestic conditions.

The drama of a boy who wants to save the crumbling family happiness fades away when we watch a truly captivating and realistic picture of the sweet high life. Apparently, the director wanted to impress the audience with his vast knowledge of the world and its imponderables. [...] Objects replace the drama, the plot, the psychology of characters, everything here. Colourful, beautiful, modern objects. [...] The whole is reminiscent of advertisements from "Life" or "Paris Match" [...] An unaware viewer might get the impression that Poznańskie słowiki was shot so that the director could have the opportunity to accumulate all these colourful marvels and show to us how he himself imagined the life of a good-hearted Pole.[12]

Watching film characters among the branded everyday objects, in designer interiors either in the cinema and more often on television (the TV series Wojna domowa [War at Home], dir. Jerzy Gruza, 1965) must have been an exciting and inspiring experience for a viewer in the "Gomułka era." Another issue is whether average Poles identified themselves with the protagonists of these films?

Today's reception of these films is different: Polish living standards do not differ so much from, say, those in Germany or France; therefore, the contemporary viewer will be rather focused on the story of the characters in the intimate interiors of their own home, etc., but I think they will have no awareness how great impression those home interiors stylized for the needs of the cinema made on the audience in the 1950 or or 196os. Looking at Magda Zawadzka (Pieczone gołabki [Baked Stuffed Cabbage], Rozwodów nie będzie [There Will Be No Divorces]), or at Kalina Jędrusik (Lekarstwo na miłość [Cure for Love]) actresses, who (as already mentioned) enjoyed a dip "in foam bath", it will be rather difficult to understand what envy these stars must have evoked in Polish women, who for many years (at least up to the time of Edward Gierek) had to wait for a personal bathroom "with white tiles." [13] From today's perspective, it will be rather an interested look of the viewer at the alluring and intelligent women who, while resting on their comfortable couch in the living room, or just taking a bath, were aware of their expectations. The same applies to other items of home decor in films. As examples it is enough to mention only a few: light cabinet wall units, fashionable chairs, white telephones (Sam pośród miasta [Alone in the City], Pingwin, Przedświąteczny wieczór,

[12] M. Keller, Żyjemy w komisie, "Kino" 1966, no. 10, p. 9 .

[13] Magda Zawadzka poses appealingly in the bath scene in the film Rozwodów nie będzie (dir. Jerzy Stefan Stawiński). Two years later she will reappear in a similar bathing scene as Tańka, the daughter of the owner of the apartment in Alekander Ścibor-Rylski's film Późne popołudnie [Late Afternoon], and three years later, as Katarzyna Zasławska in T. Chmielewski's film Pieczone gołabki she will have to stop abruptly her bath (breakdown of water supply). 
Poznańskie słowiki) or the "Moscow" fridge (Ich dzien powszedni). These items were not available in the real world for a long time. The interiors shown, among others, in films such as Przygoda noworoczna, Pingwin, Beata, Sprawa pilota Maresza, Mąż swojej żony, Żona dla Australijczyka, Sam $w$ pośród miasta, were the captivating apartments of "high society" people which were vertiginous for the average Kowalski family, and today they still arouse curiosity, but rather among historians of People's Poland, art historians and connoisseurs of vintage items.

The young intelligentsia wanted to live their own way and to realize their plans "step by step" (including those related to having a roof over their head), which even today seems to have been credibly presented in the films from those years. For the characters in these films acquiring "four corners" is often seen as a miracle, because the lack of an apartment is the cause of suffering and personal dramas. Such images can be seen, e.g. in the films Ósmy dzień tygodnia [The Eighth Day of the Week], Niewinni czarodzieje [Innocent Sorcerers] or Do widzenia do jutra [See You Tomorrow], Przygoda noworoczna [A New Year's Adventure], [Agnieszka 46]. The characters of the above films are authentic and natural. Their failures and vicissitudes of life associated with housing problems certainly could not be unknown to the majority of the audience, especially the younger ones. Agnieszka and Piotr in Ósmy dzień tygodnia are a fine couple, but the girl cannot mentally withstand the continuous separation from her beloved and the relationship falls apart. Earlier, she confesses to Piotr that "four square metres of living space at their sole disposal would be enough to secure their happiness." Unfortunately, she is denied this luxury. The phenomenal Anna Prucnal as Krystyna in Przygoda noworoczna looks appreciatively at the apartment of her boyfriend's friend, in which they welcome the New Year. "If I had an apartment like this, I would never lend it to anyone", she confesses to Adam. Bazyli admits to Pelagia in Niewinni czarodzieje that if he had money, he would certainly buy a house with three or four rooms.

The young lovers in Ósmy dzień tygodnia and Przygoda noworoczna suffer from a lack of privacy. Adam (played by Jerzy Kamas) is indeed more fortunate than Piotr (Cybulski) in Aleksander Ford's film, in fact, he receives the key to the charming apartment of his friend and goes there together with Krystyna (Anna Prucnal). The atmosphere becomes magical, the young people are happy and in love, but things get complicated because there is a woman giving birth in another apartment and her husband needs a neighbour's help. The doorbell rings and a request to call an ambulance means the end of this idyll for Krystyna and Adam. However, the several hours that the characters spent together in the cozy interiors will be remembered by the viewer for a long time. It is difficult to say today whether the aura of palpable sensuality in the film is due to the actors, Anna Prucnal and her partner Jerzy Kamas, or maybe to the beauty of the apartment. The

Through rose-tinted glasses? 
The charm and style of film intellectuals' housing intimate space certainly favours the closeness of the two protagonists. It is to be regretted that the uninvited visitor did not let them enjoy each other. The film critic in the 1960s, Konrad Eberhardt, after the release of Przygoda noworoczna, wrote that it is simply the story for that time - the story of the birth of love and its failure - suspended "between lyricism and raw realism." [14]

As an example, different to the two cases presented above, we can refer to the decision of Magdalena in the film Rozstanie [Goodbye to the Past] directed by Wojciech Jerzy Has (played by Lidia Wysocka) about the radical break in family ties by rejecting the final link, which is the house inherited from her grandfather. Years later the heroine comes to her hometown for his funeral, but she does not feel a connection with the past. "I would like to have a place on earth which I could miss wherever I am", she says to Oscar before leaving, but she knows that she must look for it elsewhere.

It is worth looking at the apartments of women - the representatives of the younger (but professionally competent) and the middle generation of the female intelligentsia from this period. The actresses playing these parts do not leave the audience in doubt that in such décor they feel "at home." This impression is made by women played by a pleiad of the most beautiful Polish actresses of the period: Iga Cembrzyńska (Janek's mother in Piata nad ranem [Five O'clock in the Morning], Monika from Otello z M2), Alina Janowska (Ina Lesko in Powrót [Return]; Zofia Kwiecińska in the fifth episode Nauczycielka [Teacher], being a part of Spóźnieni przechodnie [Those Who Are Late]; Irena Kamińska in the television series Wojna domowa [War at Home], Roksana in Poradnik matrymonialny [Matrimonial Guidebook]; Miśka in Dzięcioł [Woodpecker], Kalina Jędrusik (Joanna in Lekarstwo na miłość [Cure for Love]), Irena Krawczyk in the first episode of Zawsze w niedziele [Always on Sunday], Barbara Krafftówna (Dr Michaśka in Ich dzień powszedni [Their Common Day]), Ewa Krzyżewska (Honorata in Lekarstwo na miłość), Pola Raksa (Krysia in Rozwodów nie będzie; Beata in the movie of the same title); Zuzanna Gawlik in Kapitan Sowa na tropie [Captain Sowa Investigates], Krystyna Sienkiewicz (Janka in Lekarstwo na miłość), Aleksandra Śląska (Nitka in Ich dzień powszedni), Lucyna Winnicka (Ewa in Sam pośród miasta [Alone in the City]), Lidia Wysocka (Irena Majewska in Irena do domu [Irena, Go Home!]); Magda Zawadzka (Kasia in Rozwodów nie będzie [There Will Be No Divorces]; Katarzyna Zasławska in Pieczone gołabki [Baked Stuffed Cabbage]; Małgosia in Sublokator [Subtenant]). In their homes (mostly of the M category - situated on the new housing estates) there are no references to the middle-class[15] or
[14] K. Eberhardt, Pomiędzy liryzmem, a surowym realizmem, "Film" 1964, no. 1, p. 5.
[15] The film characters from the intelligentsia who live in middle-class homes (and feel very good there) 
the landowning tradition. [16] Apartments arranged for film heroines are cramped and have quite a few of objects, but due to the layout of rooms, large windows, light walls, small and light furniture, they tend to look spacious and functional.

The average male member of the intelligentsia remembered from the Polish films from the years 1956-1970 is a young or a youngish man trying to cope with life. He has successes with women. His apartment (often a rented room) is a stopgap, but it was still the object of envy for the majority of Poles. In general, it is an interior previously used by someone else, so it was only retrofitted with personal things or daily-use utensils necessary for the new tenant. For example, Piotr Terlecki, Agnieszka's boyfriend boy in Ósmy dzien tygodnia, [The Eighth Day of the Week] played by Zbigniew Cybulski, just had moved into a shanty house in Warsaw, which, moreover, would soon collapse. He brought with himself only books, a radio and a razor. He slept there and worked evenings at the drawing board, as he could not find a more convenient place. Another ruined apartment was inhabited by Andrzej Leszczyc (played by Jerzy Skolimowski in his Rysopis [Identification Marks: None]). A similar, provisional room was rented by Romek Brzozowski (also played by Zbigniew Cybulski) in Koniec nocy [The End of the Night] Andrzej (or Bazyli, as he introduced himself to Magda, played by Tadeusz Łomnicki) had more luck. He was an aspiring doctor in Niewinni czarodzieje [Innocent Sorcerers] and rented a cluttered studio in a prewar building. He owned an electric shaver, tape recorder, radio, scooter and... extravagant elastic socks.[17] They both treat the living space belonging to them with a distance, and for various reasons they do not identify themselves with this place. Some occupy a given space only for a time, so it is not assigned to them exclusively. In the room, where he receives petitioners, and occasionally rural dances are organized, sleeps the mayor of Białobrzegi, Zbigniew Bałcz (in the movie Agnieszka'46). Likewise, the prosecutor Deruga, a character in Niedziela sprawiedliwości [Sunday Justice] lives in a dingy hotel room. The young

include, for example, Eng. Antoni Przewłocki (played by Zdzisław Mrożewski) in Niedaleko Warszawy [Not Far from Warsaw]; Eng. Jan Wiktus (played by Zygmunt Kęstowicz) and his two wives, Helena (Ewa Wawrzoń), and Paola Campobella (Joanna Kostusiewicz) in Dwa żebra Adama [Adam's Two Ribs]; the Rosiak family: Kazimierz (Adam Mularczyk), Janina (Wanda Łuczycka) and daughter (Lidia Korsakówna) in Kariera [Career]; masseuse Maria Siankowa (Wanda Łuczycka) with daughter Tuńka (M. Zawadzka) in Późne popołudnie [Late Afternoon], in whose apartment in a glam tenement house subtenants also live, who are, treated as members of the family. In a similar apartment live an elderly intelligentsia couple:

\author{
Provisional, \\ nonchalant, bland, \\ or the cinematic \\ interiors occupied by \\ men
}

Stanisław and his wife (played by Jarema Stępowski and Ryszarda Hanin) in Sam pośród miasta.

[16] The atmosphere of mansion houses is presented, for example, in the apartment of the sisters Anna and Zofia in Czas przybliza, czas oddala [Time Past, Time Present], the first episode of the film Spóźnieni przechodnie.

[17] See the analysis of Bazyli's living space by Jean-Louis Manceau. JL. Manceau Niewinni czarodzieje, czyli tragedia złudzeń, transl. by M. Pilot. "Kwartalnik Filmowy" 1996/1997, no. 15-16, p. 230: [reprint from "Etudes cinematographique" 1968, no. 69-72, pp. 139-149]. 
poet and songwriter Leopold Górski (Krzysztof Litwin), the protagonist of Pieczone gołabki, speaks every day about life's inconveniences caused by the lack of living quarters. He has been promised an apartment, but because of benevolence, he continuously assigns each housing offer to someone in greater need.

Men bore housing difficulties with a greater patience than women, without mulling excessively over the fact that they sometimes live in quarters not fitting for a member of the intelligentsia or that regulations prevent to apply for better accommodation. In 1968, Leon Jeannot made the comedy of manners Człowiek $z M_{3}$ [Man With an Apartment], which dealt with the housing problems of Warsaw residents and revealed in a funny way the absurdities of official eligibility

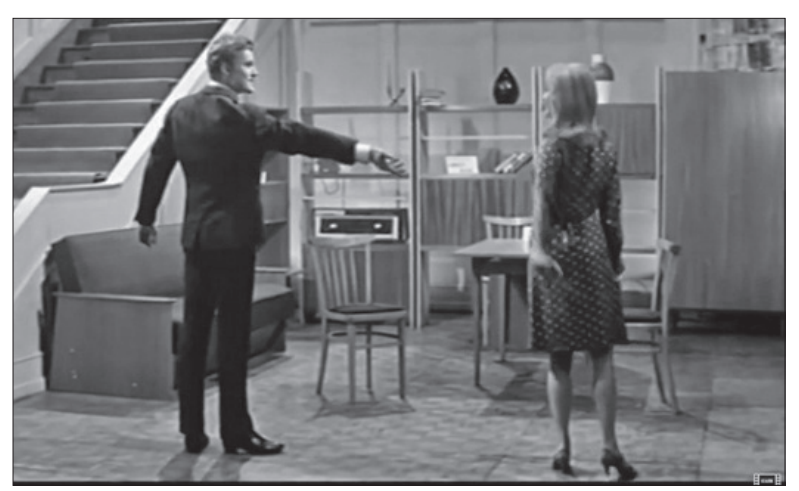
standards. The protagonist of the comedy, a young orthopedic physician Tomasz Piechocki (played by Bogumił Kobiela), receives an allocation for an M-3 apartment, but under the condition that he must be married.

Apartments on the multi-family housing estates immortalized in the Polish feature films from 1956-1970 are confirmation of the highest quality of Polish industrial design. The $\mathrm{M}_{2}$ and $\mathrm{M}_{3}$ apartments have simple, lightweight and ergonomic furniture of a small

Il. 1. Małżeństwo z rozsądku [Marriage of Convenience], 1966, dir. Stanisław Bareja. Daniel Olbrychski and Elżbieta Czyżewska in a furniture store; the rear shows the most popular furniture in the Polish People's Republic - System MK / Kowalski furniture/ size designed by Maria Chomentowska, Teresa Kruszewska, or Irena Żmudzińska; in later films they were replaced with cabinet wall units designed by Bogusława and Czesław Kowalski; armchairs were designed by Józef Chierowski, Mieczysław Puchała, and plastic-strand armchairs were designed by Kruszewska or her followers. Each home of the intelligentsia arranged for the purpose of film had to be fitted with bookshelves, bookcases or book racks. These (along with colour magazines) were displayed on elegant low tables (Warszawa [Warsaw], an episode from the Miłość dwudziestolatków [Love at Twenty]). The charm of modern windowless kitchens was emphasized by white cabinets (Lekarstwo na miłość [Cure for Love]). Guests are offered coffee or tea, and a soda siphon is laid on the low table (Katastrofa). Cigarettes are smoked and butts are extinguished in porcelain ashtrays. The interiors also contained pot plants (the most common being ferns, fig trees, sansevieria, monstera and palm trees), modern trinkets of glass or porcelain, paintings on the walls and curtains with printed colour abstract or geometric patterns. The technical equipment in the homes of the intelligentsia in the films of the late 1950 and 1960 s mandatorily included a telephone, radio, record-player, and little later (and less often) a tape-recorder and a TV set.

The film protagonists in elegant apartments were above all successful people who enjoyed modern lifestyles. They can be seen in the film of Stanisław Wohl from 1963 Przygoda noworoczna [A New Year's Adventure], but mention should also be made about the later home 
interior decorations designed by the architect Anatol Radzinowicz for the 1966 film: Mocne uderzenie [Big Beat] (dir. Jerzy Passendorfer), Małżeństwo z rozsądku ([Marriage of Convenience] dir. Stanisław Bareja), or Otello $z M_{2}$ (dir. Julian Dziedzina). It is worth looking at the interior decoration for the movie Pingwin (1963, dir. Jerzy Stefan Stawiński), which was designed by Wiesława Chojkowska (construction of decoration: Tadeusz Leple and Franciszek Garczyński; design: Roman Wołyniec). This film illustrates the levels of wealth and diverse lifestyles in Poland at the turn of 1950 s through the prism of places of residence of characters. It shows three different dwellings quarters located in the capital city, in which three befriended students of the Warsaw University of Technology (two males and one female) live with their parents. The renowned architect Paweł Bączek (with his wife and son Adam) leads an affluent but empty life. The constant trips abroad, talent and political correctness of the architect allow him to live like a lord, about which almost nobody dreamt of at that time in Poland. Andrzej, nicknamed "Penguin," also enjoys quite a comfortable existence. Thanks to the academic position of his

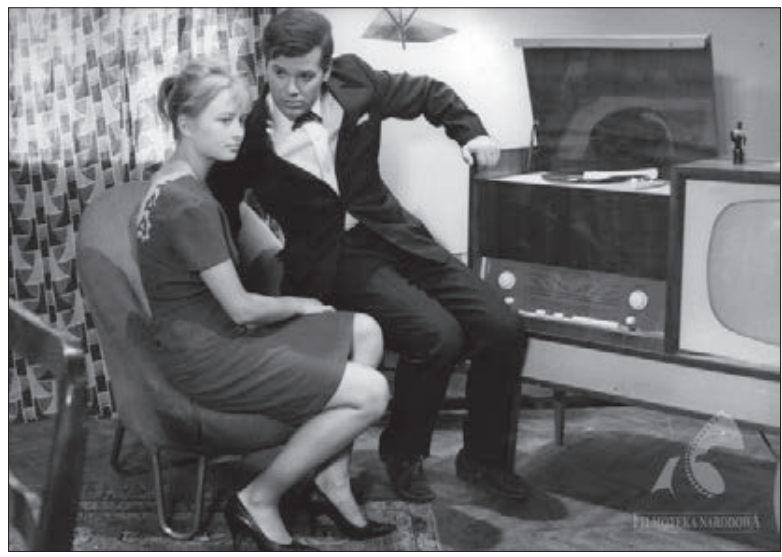
father he lives in a comfortable and modern furnished three-bedroom apartment in a new block of flats (mother is a housewife). The apartment of Baśka Oraczewska (played by Krystyna Konarska) is a painful dissonance for her and film viewers in comparisons to the apartments of her companions. The girl is the daughter of a poor seamstress, she lives in a dilapidated building on the outskirts of the city.

Films from the "Gomułka era" have their own special charm when seen today, as they simply and naturally show... the dreams of 20-, 30-, and 40-year-olds, that is, Poles born or starting their adult life in the communist era. Viewers at the time were usually aware that they were witnessing a luxury hardly attainable in real life, but they did not lose hope that they would also see their own "American Dream" come true. The ideal was to have an M-3 apartment furnished with Kowalski furniture, a "Frania" washing machine, a refrigerator, telephone, radio, record-player, TV, and a tape recorder. These items were a kind of catalogue of the needs of a large part of the population. They emphasized the pursuit of Poles who managed to make more money, and were also an important element of the lifestyle of educated, well-off and well-connected people. Those living quarters - trendy, chic, or just aesthetic, tastefully decorated and impressive cozy - reflect in different ways thehackneyed, simplistic, humorous, grotesque, propagandized or dramatic lives of the intelligentsia. The plots of those movies, set in private apartments and houses, created an aura of a social salon of which most Poles could only dream. At the same time, those films reflected faithfully contemporary design trends.

Il. 2. Fragment of Gruszka's living-room / curtains called pikasy. An armchair on metal legs and the peak of technology: a glass cabinet with a $\mathrm{TV}$, radio and a record player (Rozwodów nie będzie [There Will Be No Divorces, 1963], scenario and dir. Jerzy Stefan Stawiński; in the picture: Gruszka (Zbigniew Cybulski) and Kasia (Magdalena Zawadzka) 
Drozdowski B., Słownik wspótczesnej polszczyzny, "Kino” 1966, no. 7

Eberhardt K., Pomiędzy liryzmem a surowym realizmem, "Film" 1964, no. 1

Keller M., Żyjemy w komisie, "Kino" 1966, no. 10

Kołodziejowa B., Zakłady Porcelany “Ćmielów”, Kraków 1986

Madej K., Mieszkać w PRL, "Mówią Wieki” 2005, no. 1

Manceau J.L., Niewinni czarodzieje, czyli tragedia złudzeń transl. by M. Pilot, "Kwartalnik Filmowy" 1996/1997, no. 15-16; [przedruk za: "Etudes cimématographique" 1968, no. 69-72].

Michnik A., Gomułka - wielki i mały, rozm. przepr. Robert Walenciak, "Przegląd" 2011, no. 43.

Osęka P., Wiesław, odejdź, "Polityka" 2010, no. 51

Suchecki J., W cieniu 120000 m3 prefabrykatów rocznie, "Kronika Miasta Poznania" 2013, [no.] 3

\section{Webpages}

Speeches of Winston Churchill March 5, 1946

$<$ http://www.ntanet.net/sinewsofpeace.htm> [accessed on: 3.11.2015].

$<$ http://www.fototeka.fn.org.pl/> [accessed on: 3.11.2015]

$<$ http://www.irenasantor.pl $>$ [accessed on: 3.11.2015] 